NOMENCLATURE

Edited by Jefferson Prado, James Lendemer \& Erin Tripp

\title{
A Gordian knot: Nomenclature and taxonomy of Heterocapsa triquetra (Peridiniales: Heterocapsaceae)
}

\author{
Marc Gottschling, ${ }^{1}$ Urban Tillmann, ${ }^{2}$ Wolf-Henning Kusber, ${ }^{3}$ Mona Hoppenrath ${ }^{4}$ \& Malte Elbrächter \\ 1 Department Biologie, Systematische Botanik und Mykologie, GeoBio-Center, Ludwig-Maximilians-Universität München, \\ Menzinger Str. 67, 80638 München, Germany \\ 2 Alfred Wegener Institut, Helmholtz-Zentrum für Polar- und Meeresforschung, Am Handelshafen 12, 27570 Bremerhaven, Germany \\ 3 Botanischer Garten und Botanisches Museum Berlin, Freie Universität Berlin, Königin-Luise-Straße 6-8, 14195 Berlin, Germany \\ 4 Senckenberg am Meer, German Centre for Marine Biodiversity Research (DZMB), Südstrand 44, 26382 Wilhelmshaven, Germany \\ 5 Alfred-Wegener-Institut, Helmholtz-Zentrum für Polar- und Meeresforschung Sylt, Hafenstr. 43, 25992 List/Sylt, Germany \\ Author for correspondence: Malte Elbrächter,Malte.Elbraechter@awi.de
}

DOI https://doi.org/10.12705/671.11

\begin{abstract}
In the course of polyphasic taxonomic work in the dinophytes, we became aware of a fundamental misapplication of the name Glenodinium triquetrum (now represented conceptually by a species of Kryptoperidinium), when Stein assigned it to Heterocapsa. Possible solutions involve a conflict between retaining Ehrenberg's epithet in its correct application in the interest of priority and preserving current usage of Heterocapsa. However, we do not achieve a consensus on how to disentangle this Gordian knot, underlining that this is not a regular case of taxonomic confusion. We intend to stimulate a more general discussion about best practices in such cases, balancing between the interest of nomenclatural practicability and the respectful acknowledgement of scientific work, even if it was conducted many years ago.
\end{abstract}

Keywords conservation; dinoflagellates; Kryptoperidinium; priority; stability; typification

\section{INTRODUCTION}

In two of six Principles, the International Code of Nomenclature for algae, fungi, and plants (ICN; McNeill \& al., 2012) states that "the nomenclature of a taxonomic group is based upon priority of publication" and that there is "only one correct name, the earliest that is in accordance with the rules". This tenet corresponds to the philosophy of science in general, building and organising knowledge across generations and genealogies (and despite its judicial appearance, reliable naming of species in fact is science though information science rather than natural science; Quicke, 1993; Stock \& Stock, 2013). Occasionally, the principles of the Code are suspended through mechanisms of conservation and rejection, for example, the discovery of names in forgotten or obscure literature that predate the well-known names of important organisms (Smith \& al., 2016). Such exceptions under the rules are conceivable to assure stability of scientific names. The present contribution deals with two dinophyte species currently known as Heterocapsa triquetra (Ehrenb.) F.Stein and Kryptoperidinium foliaceum (F.Stein) Er.Lindem., which we have discovered are linked in an unfortunate way. These two distinctive species, and the corresponding names, have been widely used in marine ecological and biodiversity research since the dawn of microbiology.

Heterocapsa triquetra sensu Stein (1883) is one of the most abundant, bloom-forming dinophyte species in coastal and estuarine waters and has a global distribution (Lohmann, 1908; Paulsen, 1908; Lebour, 1925; Grontved \& Seidenfaden, 1938; Braarud \& Pappas, 1951; Balech, 1988; Hallegraeff \& al., 2010; Carstensen \& al., 2015). The species has been involved in a wide array of investigations in ecophysiology (Braarud \& Pappas, 1951; Litaker \& al., 2002), fatty acid composition (Matsuyama \& Suzuki, 1998), phagotrophy (Legrand \& al., 1998), life-history (Olli, 2004), phylogenetics (Salas \& al., 2014; Tillmann \& al., 2017) and vertical migration (Jephson \& al., 2011).

Kryptoperidinium foliaceum belongs to a unique evolutionary group of peridinialean dinophytes that harbour a diatom as a tertiary endosymbiont, the Kryptoperidiniaceae. The species has been reported from the Baltic Sea, the Mediterranean Sea, the Atlantic Ocean and the Pacific Ocean, including also the seas around Australia (Paulsen, 1908; Kempton \& al., 2002; Figueroa \& al., 2009; Hallegraeff \& al., 2010). Kryptoperidinium foliaceum has been investigated in detail in studies about life history (Figueroa \& al., 2009), ultrastructure (Dodge, 1984; Bricheux \& al., 1992; Moldrup \& al., 2013), molecular phylogenetics (Gottschling \& McLean, 2013; Kretschmann \& al., 2018) and pigment profiles (Kempton \& al., 2002).

In essence, these two taxa are widely distributed and important, have been widely studied, and the names are widely applied in the literature. Further, both are among those few

Article history: Received: 20 Apr 2017 | returned for (first) revision: 24 May 2017 | (last) revision received: 23 Jun 2017 | accepted: 9 Nov 2017 | published: online fast track, $17 \mathrm{Feb} 2018$; in print and online issues, 6 Mar 2018 || Associate Editor: James C. Lendemer || (C) International Association for Plant Taxonomy (IAPT) 2018, all rights reserved 
dinophytes, for which extensive genomic and/or transcriptomic data are available (McEwan \& al., 2008; Imanian \& al., 2011, 2012; Keeling \& al., 2014; Janouškovec \& al., 2017; Price \& Bhattacharya, 2017).

\section{HISTORICAL BACKGROUND AND TYPIFICATION OF GLENODINIUM TRIQUETRUM}

Glenodinium triquetrum Ehrenb. was originally described on the basis of samples from the Baltic Sea off Wismar (Germany), collected in 1840 (Ehrenberg, 1840). Corresponding, unpublished water-colour drawings (sheet 674, deposited at the Museum for Natural History, Berlin: BHUPM; Fig. 1) show yellow-green dinophyte cells that are ovate to elliptical in lateral view and have an eyespot (which is why the species was assigned to Glenodinium Ehrenb.: Ehrenberg, 1837). The epithet refers to the diagnostic triangular outline in lateral view, a result of ventral (and concave) flattening of the cell. Because of this distinct shape, it is evident that $G$. triquetrum has to be assigned to Kryptoperidinium Er.Lindem. (Lindemann, 1924), as that taxon is circumscribed today.
Below, we lectotypify G. triquetrum on the basis of one of the original illustrations deposited in the Ehrenberg collection at BHUPM. The lectotype designated below should be substantiated by epitypification based on material collected at the type locality and investigated with contemporary methods such as electron microscopy and molecular sequence diagnostics to assure unambiguity of the name's application.

Glenodinium triquetrum Ehrenb. in Ber. Bekanntm. Verh. Königl. Preuss. Akad. Wiss. Berlin 1840: 200. 1840 - Type: [unpub. illustration] Baltic Sea, off Germany, Mecklenburg-Vorpommern, Wismar, 5 Sep 1840 [nonfossil]: Ch.G. Ehrenberg S.n. - Lectotype (designated here): [unpub. illustration] the lower of the two cells showing a flagellum (indicated on Fig. 1) present on drawing No. 674: BHUPM!).

Other original elements: a dried mounted specimen comprising several non-fossil individuals from Baltic Sea, off Germany, Mecklenburg-Vorpommern, Wismar, without date [non-fossil]: Ch.G. Ehrenberg s.n. (BHUPM Infusionsthierchen XCIX: 540099-6! according to Jahn \& Kusber, 2004; indexed as "Glenodinium triquetrum, Wismar, Hafen").

This nomenclatural act has been registered in PhycoBank under http://phycobank.org/100008.
Fig. 1. Ehrenberg's original material of Glenodinium triquetrum Ehrenb. Water-coloured drawing (sheet 674, BHUPM). The arrow indicates the lectotype of G. triquetrum.

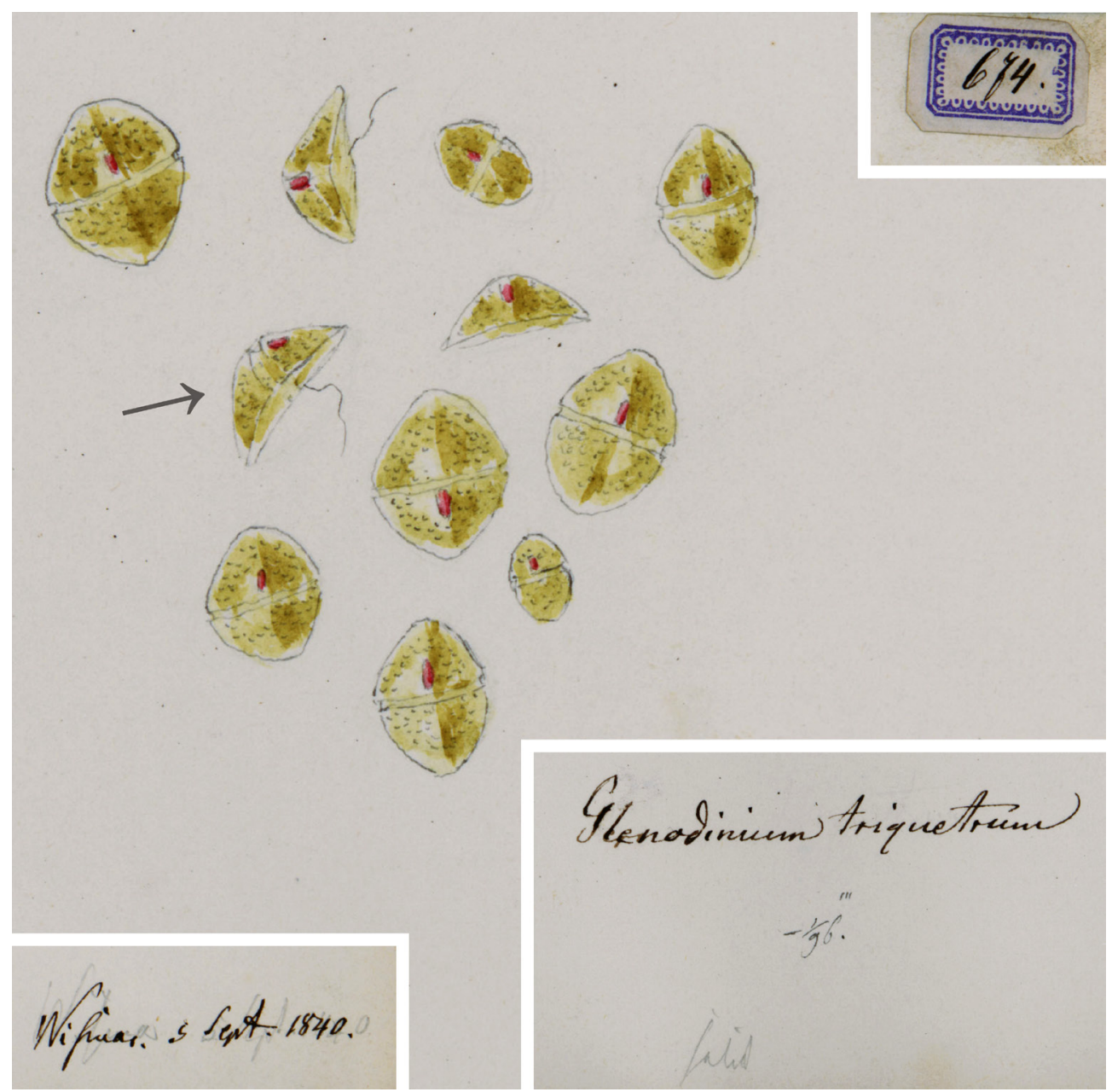




\section{THE PROBLEM}

The name Glenodinium triquetrum was only rarely cited after its publication in 1840 (Claparède \& Lachmann, 1859, 1868), until Stein (1883) used it as the main element in his new taxon Heterocapsa F.Stein. However, he clearly did not consult any of Ehrenberg's original material of G. triquetrum before publishing the new combination $H$. triquetra. In fact, he assigned to $H$. triquetra cells that shows a fusiform morphology with a mucronate antapex (Stein, 1883: pl. III figs. 30-40) (Fig. 2), a shape very different from that of Ehrenberg's original material. Even if Friedrich von Stein (1818-1885) did not see Ehrenberg's drawings, cells of the form that he attributed to $H$. triquetra are rather rhomboid and anything but triangular in lateral view (highlighted by the epithet), and are neither ovate in dorsal (or ventral) view nor yellow-green in colour (all of which is noted in Ehrenberg's protologue). Stein (1883) notably ignored the fact that an eyespot, diagnostic in Ehrenberg's original concept of Glenodinium (contrasting it with the otherwise very similar Peridinium Ehrenb.: Ehrenberg, 1837), was absent from his Baltic Sea material. Oddly, Stein illustrated a very similar form to Ehrenberg's original material on the same plate as a new species, Glenodinium foliaceum F.Stein (Stein, 1883: pl. III figs. 22-26) (Fig. 2).

During his life, Christian Gottfried Ehrenberg (1795-1876) produced about 3000 pencil and ink drawings of protists and other small organisms (Lazarus, 1998), which he regularly presented to the Royal Prussian Academy of Sciences ("Hr. Ehrenberg legte hierauf 274 Blätter von ihm selbst ausgeführter Zeichnungen von eben so vielen Arten in dem 1838 erschienenen größeren Infusorienwerke noch nicht abgebildeter Infusorien vor"; Ehrenberg, 1840: 197). However, by no means were all of the drawings published, specifically because Ehrenberg could not always afford the high printing costs (Stephan Fölske, pers. comm.). That Ehrenberg was unable to print all of his images due to financial limitations is noteworthy as Stein complained that Ehrenberg did not provide illustrations of new species (Stein, 1878: 3, 59) after his epochal Infusionsthierchen (Ehrenberg, 1838). After Ehrenberg's death in 1876, all of his collections relating to microscopic organisms, including drawings (devotedly curated by his daughter Clara, 1839-1918: Mohr \& Vogt, 2003), were deposited at the Museum for Natural History in Berlin (Germany) (Lazarus, 1998).

Given that Ehrenberg's material had been curated and deposited at an institution in Berlin, it is unclear why Stein did not consult any original material relating to G. triquetrum before publishing the new combination H. triquetra in 1883 (i.e., seven years after Ehrenberg's death). The Ehrenberg collection was a "sleeping beauty" during the 20th century, and that Stein's misapplication of G. triquetrum was overlooked by all subsequent authors might be explained by the complexity of German history, involving political isolation and subsequent limitation of access (Lazarus, 1998; Lazarus \& Jahn, 1998).

Nonetheless, Heterocapsa has problems other than the misapplication of its type. Stein (1883: 13) considered it a provisional name, and it was only validly published, because it was described under the ICZN, wherein provisional names dating to before 1961 are accepted under Art. 11.5.1. (International

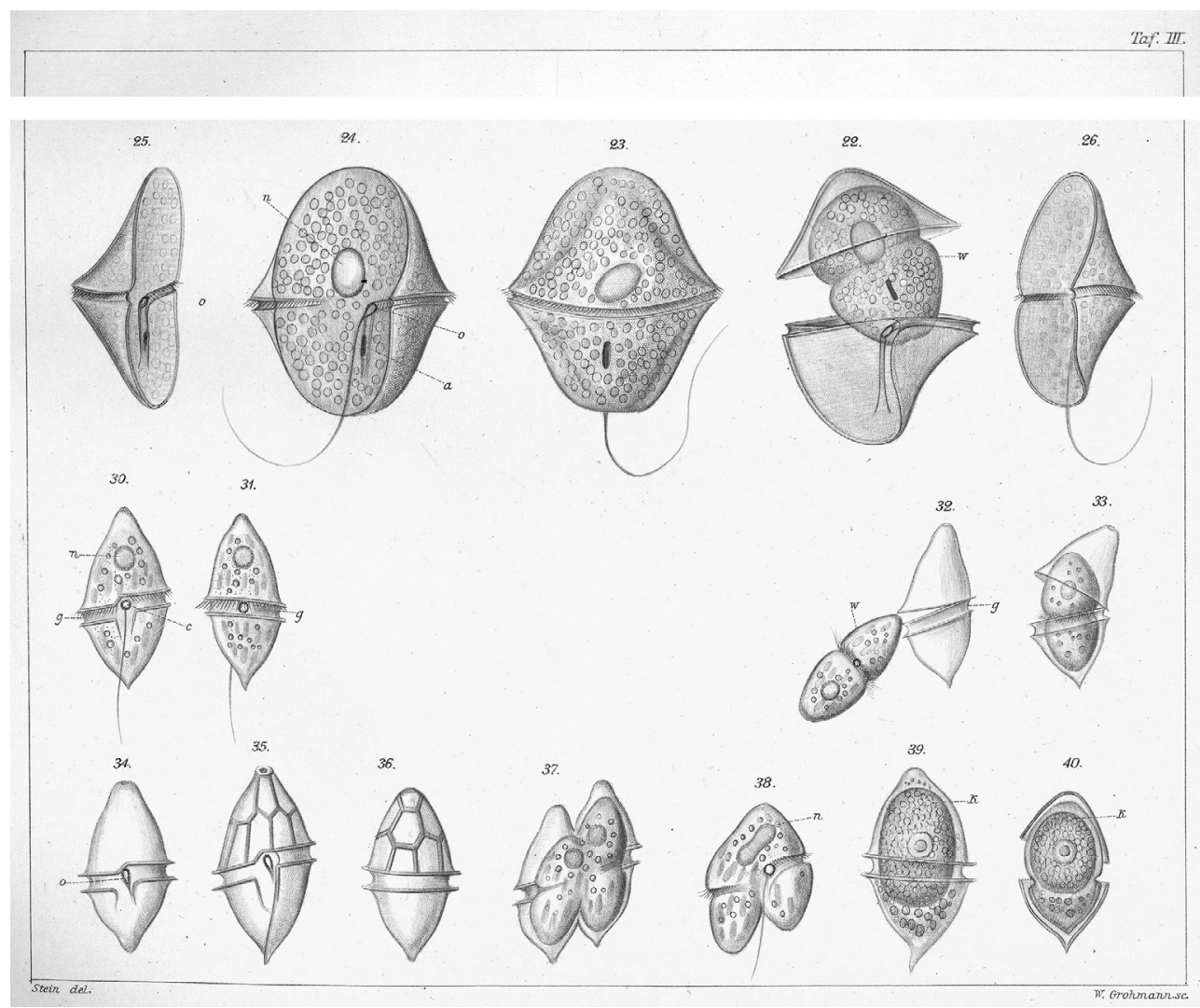

Fig. 2. Stein's original material of Heterocapsa triquetra sensu Stein (1883) non Ehrenberg (1840). Reproduction of pl. III figs. $30-40$. Note that on the same plate, original material also of Glenodinium foliaceum F.Stein (三 Kryptoperidinium foliaceum (F.Stein) Er.Lindem., putatively = Glenodinium triquetrum Ehrenb.) is depicted (pl. III figs. 22-26) [figs. 1-21 \& 27-29 omitted]. 
Commission on Zoological Nomenclature, 1999). As such, the name can be used under Art. 45.1. of the $I C N$ as well. However, Stein's treatment was inconsistent at the time he described it, as he indicated clear acceptance of the generic name in other parts of his publication (for example in the detailed legends to the figures), such that an argument could also be made for its valid publication in Stein (1883) directly under the $I C N$ rather than via the $I C Z N$ rules for provisional names. Taxonomically, Heterocapsa was heterogeneous from the very beginning, and Stein's tentativeness is further illustrated by his "provisional" assignments of two additional new species he placed in Heterocapsa. More than 80 years later, Loeblich \& Loeblich (1966: 35) selected $H$. triquetra as the type of Heterocapsa, affixing the generic name to the corresponding taxonomic concept widely applied at that time. Today, the three species originally included in Heterocapsa by Stein (1883) are considered only distantly related (Hansen, 1995; Iwataki, 2008), and none of them, as indicated by types and original material (including $H$. triquetra), actually correspond to the current concept of the generic name.

The current taxonomic concept of Heterocapsa is based on the drawings published by Stein (1883), but its nomenclatural type is that of G. triquetrum which is, in fact, a very different species that would never be classified in Heterocapsa today. It is important to recognise that we are not aware of any case, in which authors have not followed Stein's concept of Heterocapsa. In other words, the taxon has never been considered to include the dinophyte that was actually described by Ehrenberg as G. triquetrum. The consequences of the above are considerable and have the potential to cause serious nomenclatural instability and taxonomic confusion. Below, we summarise possible solutions, although we consider all of them to be disadvantageous. Basically, the question is whether priority (cf. Principles III-IV) or nomenclatural stability (cf. Preamble and Art. 14 \& 56) should be given preference in resolving the problem.

\section{(I) NO FORMAL ACTION IS TAKEN: A SOLUTION THAT WOULD CAUSE INSTABILITY}

If no formal action is taken, then two well-established generic names of dinophytes will be forced to change. Specifically, the taxonomic concept of Heterocapsa will shift from that, which has been uniformly applied for more than a century based on Stein's work, to the taxon that was originally described by Ehrenberg and which corresponds to the modern concept of Kryptoperidinium. Under such a scenario, all species currently assigned to Heterocapsa would have to be transferred to Cachonina A.R.Loebl. (Morrill \& Loeblich, 1981), Kryptoperidinium would become a later synonym of Heterocapsa requiring transfers to the latter taxon, and two common, well-studied species currently referred to as $H$. triquetra and $K$. foliaceum would be forced to change names and concepts. Particularly, the established name $H$. triquetra must be applied for a species that no one associates with. This would clearly be a case of substantial disadvantageous nomenclatural change, and the $I C N$ provides several tools for its prevention, such as measures for conservation and rejection of names (McNeill \& al., 2012).

\section{(II) CONSERVATION OF KRYPTOPERIDINIUM AGAINST HETEROCAPSA: A VIABLE SOLUTION UNLIKELY TO BE SUCCESSFUL}

A straightforward nomenclatural action would be to conserve the name Kryptoperidinium against Heterocapsa under $I C N$ Art. 14.4, as the latter currently has priority. This would acknowledge the meticulous work of Ehrenberg, but would result in the loss (perhaps at too high a price) of Stein's well-established concept of Heterocapsa and the re-assignment of its species to Cachonina. If Heterocapsa was a name of minor importance, then this procedure would probably be the best solution (compare, for example, conservation of Scrippsiella Balech, nom. cons., against Heteraulacus Diesing and Goniodoma F.Stein: Gottschling \& Elbrächter, 2015; Prud'homme van Reine, 2017).

We initially considered submitting a proposal to conserve the name "Heterocapsa triquetra F.Stein" under ICN Art. 14.9, with Stein's illustrations as a conserved type. This action would have been explicitly designed to unlink the type of the basionym from its combination. However, this strategy is contrary to the intent of the conservation provisions as reflected in the final sentence of $I C N$ Art. 14.1, which are to ensure that there is never a need to separate a name from its basionym during the conservation process. While there is no specific rule against such an action, a corresponding proposal would likely not be accepted by the General Committee (John McNeill, pers. comm.), with the result that the taxonomic confusion would remain unresolved.

\section{(III) REJECTION OF THE TYPE OF HETEROCAPSA: ANOTHER UNWORKABLE SOLUTION}

As Stein (1883: 13) reassigned Ehrenberg's G. triquetrum to Heterocapsa, no other legitimate, validly published name exists for the taxon H. triquetra sensu Stein (1883) (but see Tillmann $\&$ al., 2017). We therefore deliberated on the description of a new species typified with Stein's illustrations. As a next step, we considered proposing rejection of the lectotypification of Heterocapsa with H. triquetra (Loeblich \& Loeblich, 1966: $35)$, because it is in serious conflict with Stein's protologue (ICN Art. 9.19.(b)). Under this scenario, Heterocapsa would be untypified, and thus we could propose lectotypification of Heterocapsa with our "new" species. We believed this to be a workable solution, as the potential holotype of our new species (pl. III 35 in Stein, 1883) is original material of Heterocapsa in the sense of the ICN (Art. 9.2-9.3). However, the lectotype of a generic name must be selected from among the types of the species validly published in the protologue (Art. 10.2). As none of the original elements of the species names included by Stein (1883) corresponds to the current usage of Heterocapsa, this solution is also not feasible. 


\section{- (IV) A CONSERVED TYPE FOR GLENODINIUM TRIQUETRUM: AN ALTERNATE SOLUTION THAT WOULD FORMALISE PAST ERRORS}

To the best of our knowledge, no one has applied Ehrenberg's epithet "triquetrum" since 1883 in any sense other than that of Stein (1883). The easiest solution would be to preserve that usage under ICN Art. 14.9 with a conserved type, thereby retaining the current usage of $H$. triquetra and avoiding the need to disrupt the nomenclature of any species assigned to Kryptoperidinium. A corresponding proposal to the General Committee of the $I C N$ would most likely be considered more acceptable, but it would be the most polarising approach for phycological taxonomists. Specifically, it would formalise the change in Ehrenberg's original concept because of Stein's error, who would consequently be rewarded by both confirming his concept of $H$. triquetra and maintenance of $K$. foliaceum. This would be particularly unfortunate because Ehrenberg's concept of the taxon is documented by extant specimens and original drawings, with a collection date and type locality clearly given, whereas Stein's hitherto unnamed species of Heterocapsa is supported by no extant specimens, and lacks both a clear collection date (probably late summer 1879: Wetzel, 1885) and type locality.

\section{CONCLUSIONS}

As we have outlined in the preceding sections, the rules of the $I C N$ do not provide a path to resolve the nomenclature of Heterocapsa that will be considered palatable to all phycologists. Instead, we are presented with a situation wherein conservation of Kryptoperidinium against Heterocapsa would run contrary to the intent of conservation. Likewise, rejection of the Heterocapsa lectotypification appears unfeasible, and conservation of the type of G. triquetrum would have the unfortunate result of formalising a major error made by Stein (1883) that has been perpetuated by phycologists for more than a century. Importantly, the latter option corresponds well to contemporary proposals to address on a large scale the nomenclatural chaos that can be created re-examining old names and their types. Such proposals including that to effectively supress neglected names in "forgotten literature" published earlier than 1970 (Smith \& al., 2016), and the possibility of transitioning to an informal naming system for algae rather than continuing to use the Linnaean binomial system (De Clerck \& al., 2013). Although we could not reach a consensus on how the present problem should be addressed, we do agree that such pragmatism ignores the fact that seeming instability and confusion in nomenclature, because of priority, will often become accepted once resolved within a single researcher's generation, or even a shorter period. A meaningful graph how acceptance of a new/old name may take some time is shown in Koch \& German, 2013, for Noccaea caerulescens (J.Presl \& C.Presl) F.K.Mey. (Brassicaceae), formerly known as Thlaspi caerulescens J.Presl \& C.Presl. Similarly, the name Scrippsiella acuminata (Ehrenb.) Kretschmann \& al. (Thoracosphaeraceae) has been accepted in favour of the formerly established name Scrippsiella trochoidea (F.Stein) A.R.Loebl. (Luo \& al., 2016; Craveiro \& al., 2017; Rubino \& al., 2017; Tse \& Lo, 2017) shortly after its taxonomic clarification (Kretschmann \& al., 2015).

From our perspective, attempts to supress older works or forgotten names undermine our own modern research by seeking to discard the work of scientists of previous centuries. Indeed, this would establish a dangerous precedent that could be used by future researchers to supress the work of today. Rather than viewing the ever increasing accessibility of online literature and specimen data, we should seize the moment "to put the nomenclature of the past into order" (Preamble of the $I C N$ ) through detailed and careful integrative study.

The Ehrenberg collection hosted at the Museum of Natural History in Berlin provides an excellent example of the opportunities that modern access to collections and literature can afford. It was inaccessible for decades but today, the drawings are digitised (Lazarus, 1998; Lazarus \& Jahn, 1998) and available online, including many of taxonomic importance. We can at last be impressed by the productivity and talents of Ehrenberg and other early scientists. This admiration will hopefully better guide us to make decisions that balance scientific priority and nomenclatural stability in difficult cases such as the present one.

\section{AUTHOR CONTRIBUTIONS}

MG and UT discovered the unfortunate link between Heterocpasa triquetra (Ehrenb.) F.Stein and its basionym. All authors discussed the nomenclatural and taxonomic consequences and possible solutions for the resulting confusion and phrased the text together. - MG, https://orcid. org/0000-0002-4381-8051; UT, https://orcid.org/0000-0002-8207-4382

\section{ACKNOWLEDGEMENTS}

We thank John McNeill (Edinburgh) and Nick Turland (Berlin) for intense discussions about possible solutions of the taxonomical problem. David Lazarus (BHUPM, Berlin) provided access to the Ehrenberg collection and was responsible for digitising valuable original material. Robert A. Fensome (Dartmouth) provided many valuable comments to a first draft of the manuscript that are also acknowledged here. We further thank James Lendemer (New York) for many invaluable suggestions to improve our survey during the review process.

\section{口 LITERATURE CITED}

Balech, E. 1988. Los Dinoflagelados del Atlantico sudoccidental. Madrid: Museo Argentino de Ciencias Naturales "R. Rivadavia".

Braarud, T. \& Pappas, I. 1951. Experimental studies on the dinoflagellate Peridinium triquetrum (Ehrb.) Lebour. Norske Vidensk.-Akad., Mat.-Naturvidensk. Kl., Avh. 2: 1-23.

Bricheux, G., Mahoney, D.G. \& Gibbs, S.P. 1992. Development of the pellicle and thecal plates following ecdysis in the dinoflagellate Glenodinium foliaceum. Protoplasma 168: 159-171. https://doi.org/10.1007/BF01666262 
Carstensen, J., Klais, R. \& Cloern, J.E. 2015. Phytoplankton blooms in estuarine and coastal waters: Seasonal patterns and key species. Estuarine Coastal Shelf Sci. 162: 98-109. https://doi.org/10.1016/j.ecss.2015.05.005

Claparède, E. \& Lachmann, J. 1859. Études sur les infusoires et les rhizopodes. Mém. Inst. Natl. Genevois 6: 261-467.

Claparède, E. \& Lachmann, J. 1868. Études sur les infusoires et les rhizopodes. Genève et Bale [Geneva and Basel]: H. Georg. https://doi.org/10.5962/bhl.title.29753

Craveiro, S.C., Daugbjerg, N., Moestrup, Ø. \& Calado, A.J. 2017. Studies on Peridinium aciculiferum and Peridinium malmogiense (= Scrippsiella hangoei): Comparison with Chimonodinium lomnickii and description of Apocalathium gen. nov. (Dinophyceae). Phycologia 56: 21-35. https://doi.org/10.2216/16-20.1

De Clerck, O., Guiry, M.D., Leliaert, F., Samyn, Y. \& Verbruggen, H. 2013. Algal taxonomy: A road to nowhere? J. Phycol. 49: 215225. https://doi.org/10.1111/jpy. 12020

Dodge, J.D. 1984. The functional and phylogenetic significance of dinoflagellate eyespots. Biosystems 16: 259-267. https://doi.org/10.1016/0303-2647(83)90009-6

Ehrenberg, C.G. 1837. Zusätze zur Erkenntnis großer organischer Ausbildung in den kleinsten thirischen Organismen. Abh. Königl. Akad. Wiss. Berlin 1835: 151-180.

Ehrenberg, C.G. 1838. Die Infusionsthierchen als vollkommene Organismen. Leipzig: Voss. https://doi.org/10.5962/bhl.title.97605

Ehrenberg, C.G. 1840. [274 Blätter von ihm selbst ausgeführter Zeichnungen von eben so vielen Arten]. Ber. Bekanntm. Verh. Königl. Preuss. Akad. Wiss. Berlin 1840: 197-219.

Figueroa, R.I., Bravo, I., Fraga, S., Garces, E. \& Llaveria, G. 2009 The life history and cell cycle of Kryptoperidinium foliaceum, a dinoflagellate with two eukaryotic nuclei. Protist 160: 285-300. https://doi.org/10.1016/j.protis.2008.12.003

Gottschling, M. \& Elbrächter, M. 2015. (2382) Proposal to conserve the name Scrippsiella against Heteraulacus and Goniodoma (Thoracosphaeraceae, Dinophyceae). Taxon 64: 1051-1052. https://doi.org/10.12705/645.18

Gottschling, M. \& McLean, T.I. 2013. New home for tiny symbionts: Dinophytes determined as Zooxanthella are Peridiniales and distantly related to Symbiodinium. Molec. Phylogen. Evol. 67: 217222. https://doi.org/10.1016/j.ympev.2013.01.003

Grontved, J.U.L. \& Seidenfaden, G. 1938. The phytoplankton of the waters west of Greenland. Meddel. Grønland. 82: 1-380.

Hallegraeff, G.M., Bolch, C.J.S., Hill, D.R.A., Jameson, I., Leroi, J.-M., McMinn, A., Murray, S., de Salas, M.F. \& Saunders, K.M. 2010. Phytoplankton of temperate coastal waters. Canberra: CSIRO.

Hansen, G. 1995. Analysis of the thecal plate pattern in the dinoflagellate Heterocapsa rotundata (Lohmann) comb. nov. (= Katodinium rotundatum (Lohmann) Loeblich). Phycologia 34: 166-170. https://doi.org/10.2216/10031-8884-34-2-166.1

Imanian, B., Pombert, J.-F. \& Keeling, P.J. 2011. The complete plastid genomes of the two 'dinotoms' Durinskia baltica and Kryptoperidinium foliaceum. PLoS ONE 5: e10711. https://doi.org/10.1371/journal.pone.0010711

Imanian, B., Pombert, J.-F., Dorrell, R.G., Burki, F. \& Keeling, P.J. 2012. Tertiary endosymbiosis in two dinotoms has generated little change in the mitochondrial genomes of their dinoflagellate hosts and diatom endosymbionts. PLOS ONE 7: e43763. https://doi.org/10.1371/journal.pone.0043763

International Commission on Zoological Nomenclature 1999. International code of zoological nomenclature, ed. 4. London: International Trust for Zoological Nomenclature.

Iwataki, M. 2008. Taxonomy and identification of the armored dinoflagellate genus Heterocapsa (Peridiniales, Dinophyceae). Plankt. Benthos Res. 3: 135-142. https://doi.org/10.3800/pbr.3.135

Jahn, R. \& Kusber, W.-H. $20 \overline{04}$. Algae of the Ehrenberg collection - 1. Typification of 32 names of diatom taxa described by C.G. Ehrenberg. Willdenowia 34: 577-595.https://doi.org/10.3372/wi.34.34219
Janouškovec, J., Gavelis, G.S., Burki, F., Dinh, D., Bachvaroff, T.R., Gornik, S.G., Bright, K.J., Imanian, B., Strom, S.L., Delwiche, C.F., Waller, R.F., Fensome, R.A., Leander, B.S., Rohwer, F.L. \& Saldarriaga, J.F. 2017. Major transitions in dinoflagellate evolution unveiled by phylotranscriptomics. Proc. Natl. Acad. Sci. U.S.A. 114: E171-E180. https://doi.org/10.1073/pnas.1614842114

Jephson, T., Fagerberg, T. \& Carlsson, P. 2011. Dependency of dinoflagellate vertical migration on salinity stratification. Aquat. Microbial Ecol. 63: 255-264. https://doi.org/10.3354/ame01498

Keeling, P.J., Burki, F., Wilcox, H.M., Allam, B., Allen, E.E., Amaral-Zettler, L.A., Armbrust, E.A., Archibald, J.M., Bharti, A.K., Bell, C.J., Beszteri, B., Bidle, K.D., Cameron, C.T., Campbell, L., Caron, D.A., Cattolico, R.A. Collier, J.L., Coyne, K., Davy, S.K., Deschamps, P., Dyhrman, S.T., Edvardsen, B., Gates, R.D., Gobler, C.J., Greenwood, S.J., Guida, S.M., Jacobi, J.L., Jakobsen, K.S., James, E.R., Jenkins, B., John, U., Johnson, M.D., Juhl, A.R., Kamp, A., Katz, L.A., Kiene, R., Kudryavtsev, A., Leander, B.S., Lin, S., Lovejoy, C., Lynn, D., Marchetti, A., McManus, G., Nedelcu, A.M., Menden-Deuer, S., Miceli, C., Mock, T., Montresor, M., Moran, M.A., Murray, S., Nadathur, G., Nagai, S., Ngam, P.B., Palenik, B., Pawlowski, J., Petroni, G., Piganeau, G., Posewitz, M.C., Rengefors, K., Romano, G., Rumpho, M.E., Rynearson, T., Schilling, K.B., Schroeder, D.C., Simpson, A.G.B., Slamovits, C.H., Smith, D.R., Smith, G.J., Smith, S.R., Sosik, H.M., Stief, P., Theriot, E., Twary, S.N., Umale, P.E., Vaulot, D., Wawrik, B., Wheeler, G.L., Wilson, W.H., Xu, Y., Zingone, A. \& Worden, A.Z. 2014 The Marine Microbial Eukaryote Transcriptome Sequencing Project (MMETSP): Illuminating the functional diversity of eukaryotic life in the oceans through transcriptome sequencing. PLoS Biol. 12: e1001889. https://doi.org/10.1371/journal.pbio.1001889

Kempton, J., Wolny, J.L., Tengs, T., Rizzo, P., Morris, R., Tunnell, J., Scott, P., Steidinger, K.A., Hymel, S. \& Lewitus, A. 2002. Kryptoperidinium foliaceum blooms in South Carolina: A multianalytical approach to identification. Harmful Algae 1: 383-392. https://doi.org/10.1016/S1568-9883(02)00051-3

Koch, M.A. \& German, D.A. 2013. Taxonomy and systematics are key to biological information: Arabidopsis, Eutrema (Thellungiella), Noccaea and Schrenkiella (Brassicaceae) as examples. Frontiers Pl. Sci. (Lausanne) 4: 267. https://doi.org/10.3389/fpls.2013.00267

Kretschmann, J., Elbrächter, M., Zinlsmeister, C., Söhner, S., Kirsch, M., Kusber, W.-H. \& Gottschling, M. 2015. Taxonomic clarification of the dinophyte Peridinium acuminatum Ehrenb., EScrippsiella acuminata, comb. nov. (Thoracosphaeraceae, Peridiniales). Phytotaxa 220: 239-256. https://doi.org/10.11646/phytotaxa.220.3.3

Kretschmann, J., Žerdoner Čalasan, A. \& Gottschling, M. 2018. Molecular phylogenetics of dinophytes harbouring diatoms as endosymbionts (Kryptoperidiniaceae, Peridiniales), with evolutionary interpretations and a focus on the identity of Durinskia oculata from Prague. Molec. Phylogen. Evol. 118: 392-402. https://doi.org/10.1016/j.ympev.2017.10.011

Lazarus, D.B. 1998. The Ehrenberg Collection and its curation. Pp. 31-48 in: Williams, D.M. \& Huxley, R. (eds.), Christian Gottfried Ehrenberg (1795-1876): The man and his legacy. London: The Linnean Society.

Lazarus, D.B. \& Jahn, R. 1998. Using the Ehrenberg collection. Diatom Res. 13: 273-291. https://doi.org/10.1080/0269249X.1998.9705451

Lebour, M.V. 1925. The dinoflagellates of the Northern seas. Plymouth: The Marine Biological Association of the United Kingdom.

Legrand, C., Graneli, E. \& Carlsson, P. 1998. Induced phagotrophy in the photosynthetic dinoflagellate Heterocapsa triquetra. Aquat. Microbial Ecol. 15: 65-75. https://doi.org/10.3354/ame015065

Lindemann, E.B.L.W. 1924. Der Bau der Hülle bei Heterocapsa und Kryptoperidinium foliaceum (Stein) n. nom. Bot. Arch. 5: 114-120.

Litaker, R.W., Warner, V.E., Rhyne, C., Duke, C.S., Kenney, B.E., Ramus, J. \& Tester, P.A. 2002. Effect of diel and interday variations 
in light on the cell division pattern and in situ growth rates of the bloom-forming dinoflagellate Heterocapsa triquetra. Mar. Ecol. Progr. Ser. 232: 63-74. https://doi.org/10.3354/meps232063

Loeblich, A.R., Jr. \& Loeblich, A.R., III 1966. Index to the genera, subgenera, and sections of the Pyrrhophyta. Stud. Trop. Oceanogr. 3: $1-94$.

Lohmann, H. 1908. Untersuchungen zur Feststellung des vollständigen Gehaltes des Meeres an Plankton. Wiss. Meeresuntersuch., Abt. Kiel 10: 129-370.

Luo, Z., Mertens, K.N., Bagheri, S., Aydin, H., Takano, Y., Matsuoka, K., McCarthy, F.M.G. \& Gu, H. 2016. Cyst-theca relationship and phylogenetic positions of Scrippsiella plana sp. nov. and S. spinifera (Peridiniales, Dinophyceae). Eur. J. Phycol. 51: 188-202. https://doi.org/10.1080/09670262.2015.1120348

Matsuyama, Y. \& Suzuki, T. 1998. Free fatty acid in Heterocapsa circularisquama and Heterocapsa triquetra (Dinophyceae). Fish. Sci. 64: 662-663. https://doi.org/10.2331/fishsci.64.662

McEwan, M., Humayun, R., Slamovits, C.H. \& Keeling, P.J. 2008. Nuclear genome sequence survey of the dinoflagellate Heterocapsa triquetra. J. Eukar. Microbiol. 55: 530-535. https://doi.org/10.1111/j.1550-7408.2008.00357.x

McNeill, J., Barrie, F.R., Buck, W.R., Demoulin, V., Greuter, W., Hawksworth, D.L., Herendeen, P.S., Knapp, S., Marhold, K., Prado, J., Prud'homme van Reine, W.F., Smith, G.F., Wiersema, J.H. \& Turland, N.J. (eds.) 2012. International Code of Nomenclature for algae, fungi, and plants (Melbourne Code): Adopted by the Eighteenth International Botanical Congress Melbourne, Australia, July 2011. Königstein: Koeltz Scientific Books.

Mohr, B.A.R. \& Vogt, A. 2003. Berliner Geowissenschaftlerinnen an der Friedrich-Wilhelms-Universitat von 1906 bis 1945, eine Fallstudie. Mitt. Mus. Naturk. Berlin, Geowiss. Reihe [= Foss. Rec.] 6: 53-69. https://doi.org/10.1002/mmng.20030060103

Moldrup, M., Moestrup, Ø. \& Hansen, P.J. 2013. Loss of phototaxis and degeneration of an eyespot in long-term algal cultures: Evidence from ultrastructure and behaviour in the dinoflagellate Kryptoperidinium foliaceum. J. Eukar. Microbiol. 60: 327-334. https://doi.org/10.1111/jeu.12036

Morrill, L.C. \& Loeblich, A.R., III 1981. A survey for body scales in dinoflagellates and a revision of Cachonina and Heterocapsa (Pyrrhophyta). J. Plankt. Res. 3: 53-66. https://doi.org/10.1093/plankt/3.1.53

Olli, K. 2004. Temporary cyst formation of Heterocapsa triquetra (Dinophyceae) in natural populations. Mar. Biol. 145: 1-8. https://doi.org/10.1007/s00227-004-1295-9

Paulsen, O. 1908. XVIII. Peridiniales. Pp. I-124 in: Brandt, K. \& Apstein, C. (eds.), Nordisches Plankton: Botanischer Teil. Kiel and Leipzig: Lipsius \& Tischer. https://doi.org/10.5962/bhl.title.918
Price, D.C. \& Bhattacharya, D. 2017. Robust Dinoflagellata phylogeny inferred from public transcriptome databases. J. Phycol. 53: 725729. https://doi.org/10.1111/jpy.12529

Prud'homme van Reine, W.F. 2017. Report of the Nomenclature Committee for Algae: 15. Taxon 66: 191-192. https://doi.org/10.12705/661.16

Quicke, D.L.J. 1993. Principles and techniques of contemporary taxonomy. London: Blackie Academic \& Professional. https://doi.org/10.1007/978-94-011-2134-7

Rubino, F., Belmonte, M. \& Gall, B.S. 2017. Plankton resting stages in recent sediments of Haifa port, Israel (Eastern Mediterranean) Distribution, viability and potential environmental consequences. Mar. Pollut. Bull. 116: 258-269. https://doi.org/10.1016/j.marpolbul.2016.12.078

Salas, R., Tillmann, U. \& Kavanagh, S. 2014. Morphological and molecular characterization of the small armoured dinoflagellate Heterocapsa minima (Peridiniales, Dinophyceae). Eur. J. Phycol. 49: 413-428. https://doi.org/10.1080/09670262.2014.956800

Smith, G.F., Figueiredo, E. \& Moore, G. 2016. Increasing nomenclatural stability by preventing the introduction of long-forgotten names that will compete with ones in use: A solution must be found, and soon. Taxon 65: 1385-1390. https://doi.org/10.12705/656.11

Stein, F. von 1878. Der Organismus der Infusionsthiere: Nach eigenen Forschungen in systematischer Reihenfolge bearbeitet, 3. Abth., Die Naturgeschichte der Flagellaten oder Geißelinfusorien, 1. Hälfte, Den noch nicht abgeschlossenen Theil nebst Erklärung der sämtlichen Abbildungen enthaltend. Leipzig: Engelmann. https://doi.org/10.5962/bhl.title.3933

Stein, F. von 1883. Der Organismus der Infusionsthiere: Nach eigenen Forschungen in systematischer Reihenfolge bearbeitet, 3. Abth., 2. Hälfte, Die Naturgeschichte der arthrodelen Flagellaten. Leipzig: Engelmann. https://doi.org/10.5962/bhl.title.3933

Stock, W.G. \& Stock, M. 2013. Handbook of Information Science. Munich: De Gruyter. https://doi.org/10.1515/9783110235005

Tse, S.P.K. \& Lo, S.C.L. 2017. Comparative proteomic studies of a Scrippsiella acuminata bloom with its laboratory-grown culture using a ${ }^{15} \mathrm{~N}$-metabolic labeling approach. Harmful Algae 67: 26-35. https://doi.org/10.1016/j.hal.2017.05.009

Tillmann, U., Hoppenrath, M., Gottschling, M., Kusber, W.-H. \& Elbrächter, M. 2017. Plate pattern clarification of the marine dinophyte Heterocapsa triquetra sensu Stein (Dinophyceae) collected at the Kiel Fjord (Germany). J. Phycol. 53: 1305-1324. https://doi.org/10.1111/jpy.12584

Wetzel, J. 1885. Hofrath Friedrich Ritter von Stein. Lotos 34: XXIII-XXXII. 